Agnieszka Jakuboszczak

Zaktad Historii Nowożytnej do XVIII wieku

Instytut Historii

Uniwersytet im. Adama Mickiewicza w Poznaniu

\title{
O życiu rodzinnym i edukacji córek księcia Franciszka Ksawerego de Saxe w świetle dokumentów Archives départemantales de l'Aube
}

\begin{abstract}
Agnieszka Jakuboszczak, On Family Life and Education of the Daughters of Prince Francis Xavier of Saxony in the Light of the Documents of the Archives departemantales de l'Aube
\end{abstract}

Francis Xavier of Saxony, the son of Augustus III, Elector of Saxony and King of Poland, left a very extensive correspondence, which has been preserved until our times in the Departmental Archives in Troyes. The collection constitutes a very important source for the history of everyday life and the history of education of aristocracy in the 18th century. A part of the collection is available in the electronic version on the website of the Archives. Numerous children of the Prince, the sons, as well as daughters, obtained the education suitable for the royal family - comprehensive, competent, pursuing the spirit of the Enlightenment. The period of pursuing knowledge by the children of Francis Xavier was not the time of severing the ties with the parents. The relationships between the father and his sons and daughters were lasting and became more intense in the course of time. Carefully selected tutors and governesses were a very important link between the Prince and his wife and the children. Preceptors not only controlled the educational progress, but also every aspect of daily life, especially of the girls. The Prince expected detailed reports which facilitated control over the adolescent boys and girls, for whom best matches for marriage were being arranged. A complex world of relationships of Francis Xavier's family completes for us the picture of everyday life of the ruling families, so often confined by the tight restraints of the ceremonial.

Keywords: family life, education of the daughters, prince Francis Xavier of Saxony

Personnage qui a traversé l'Histoire avec des pantoufles ${ }^{1}$ - taki obraz Franciszka Ksawerego Saskiego, drugiego syna Augusta III Wettyna, króla Polski i elektora Sakso-

${ }^{1}$ Osobistość, która przeszła przez Historię w kapciach. J.-J. Vernier, Etude biographique sur le Prince Xavier de Saxe comte de Lusace, précédée d'une notice sur le fonds de Saxe conservé aux Archives départementales de l'Aube, Troyes 1903, s. XIV. 
nii, utrwaliła dziewiętnastowieczna historiografia francuska. Wiele jednak znaczących wydarzeń z połowy XVIII w. dotyczyło bezpośrednio Ksawerego. Był on drugim synem Augusta III Wettyna, sekretnym kandydatem Ludwika XV do korony polskiej, wujkiem trzech królów Francji, regentem w Saksonii na czas małoletniości bratanka, dowódcą W wojnie siedmioletniej (1756-1763), księciem spokrewnionym i spowinowaconym z większością rodzin panujących w Europie.

Choć wydaje się, że życie księcia, który nigdy nie piastował przez dłuższy czas pierwszoplanowej funkcji politycznej, nie powinno pozostawić większych śladów, to zachowane archiwalia są imponujące. Korespondencja gromadzona pieczołowicie przez księcia w zamku Pont-sur-Seine została skonfiskowana przez władzę rewolucyjnej Francji i zdeponowana w Archiwum departamentalnym Aube w Troyes w 1797 r. Sam książę Franciszek Ksawery, uciekając na początku 1791 r. ze swoich dóbr, zabrał jedynie szkatułkę i najwartościowsze klejnoty. Na miejscu pozostało całe wyposażenie zamku: obrazy, biblioteka i osobiste archiwum. Zachowane materiały usystematyzowano w XIX w., jednak pozostały one w większości niewykorzystane przez badaczy ${ }^{2}$. Niewątpliwie fakt ten można wiązać z objętością zespołu Fonds de Saxe³, w skład którego wchodzi około 50 tys. listów od 840 korespondentów. Poza listami zachowały się także brudnopisy z lat 1744-1790, w tym liczne autografy księcia, w formie zapisków na luźnych kartach, jak i oprawionych ksiąg in-folio ${ }^{4}$. Kolejną część zespołu archiwalnego stanowią liczne raporty i zapiski, które dostarczają istotnych informacji z punktu widzenia biografii księcia, sytuacji politycznej w Saksonii i Europie. Materiał jest niewyczerpanym źródłem licznych anegdot. Warto więcej uwagi poświęcić korespondencji, która charakteryzuje się przede wszystkim różnorodnością. Korespondencja prywatna to przede wszystkim listy rodziny: braci i sióstr, szwagrów, szwagierek i bratowych, dzieci, kochanek i przyjaciół. Drugą grupę stanowią listy o tematyce politycznej i wojskowej, przesłane przez władców, urzędników, dyplomatów. Ostatnia grupa korespondencji dotyczy spraw związanych z administracją, liczne zapytania i podziękowania, w języku niemieckim i włoskim. W latach 2004-2005 na uniwersytecie Paris IV Sorbonne powstała praca magisterska, której bazą źródłową była właśnie korespondencja Franciszka Ksawerego ${ }^{5}$.

${ }^{2}$ P. Guinard, Rapport sur les papiers de SAR le Prince François Xavier de Saxe, par..., Dijon 1853; A. Thévenot, Correspondance inédite du Prince François Xavier de Saxe, par..., Paris 1874; C. Breard, Correspondance inédite du Général-Major de Martange, aide de camp du Prince Xavier de Saxe, lieutenant général des Armées (1756-1782), Paris 1898. Zob. Prèsentation du projet Xavier de Saxe, http://www.archivesaube.fr/arkotheque/fond_de_saxe/presentation.php.

${ }^{3}$ Zespół Fonds de Saxe dzieli się na dwie części. Pierwsza z nich składa się z archiwaliów osobistych księcia Ksawerego, druga to dokumentacja dotycząca domeny Pont-sur-Seine, zamku oraz majątku Chaumont, pierwszych dóbr zakupionych we Francji, i rezydencji w Paryżu.

${ }^{4}$ A. Thévenot, op. cit., s. IX.

${ }^{5}$ C. Terraux, Le Prince Xavier de Saxe. Correspondance et réseaux d'une maison princière dans l'Europe du XVIIIe siècle. Mémoire de maîtrise d'Histoire Moderne sous la direction de Monsieur le Professeur Lucien Bély, Université Paris-Sorbonne, Paris 2004-2005 (wersja dostępna w internecie, z której korzystałam, nie jest paginowana). 
Franciszek Ksawery ${ }^{6}$ (25 VIII 1730-21 VI 1806) był jednym z czternaściorga dzieci, które urodziły się z małżeństwa Augusta III Wettyna (1696-1763) z Marią Józefą (1731-1767), córką cesarza Józefa I (1678-1711). Elektor saski kierował się w wytyczeniu drogi edukacji swoich dzieci, a zwłaszcza synów, tym, w jaki sposób on sam był kształcony. Reguły, które zastosowano wobec niego były praktykowane już przy edukacji Augusta II, jego ojca. August III interesował się wszystkim, co działo się z jego dziećmi, a zwłaszcza synami. Córkom poświęcał więcej uwagi, gdy były przy nadziei, natomiast niezamężne pozostawały na uboczuํ. Siostry Franciszka Ksawerego otrzymały wykształcenie typowe dla dziewcząt z rodów książęcych. Ich edukacja nakierowana była na zdobycie umiejętności śpiewu, gry na instrumentach oraz występów aktorskich. Uczyły się języków obcych i przyswajały ogólną wiedzę. Gdy Ksawery pokonywał kolejne szczeble kariery wojskowej, jego siostry zbierały pierwsze doświadczenia w szerokim świecie. Książę bardzo cenił sobie więzi łączące go z rodziną, czego świadectwem jest trochę ponad cztery tysiące czterysta listów od braci i sióstro ${ }^{8}$. Serdeczne relacje odnalazły swoje odzwierciedlenie m.in. w żartobliwych i pieszczotliwych przezwiskach: Franciszek Ksawery zwany był „Waser” lub „Xixi”, a jego siostry Maria Anna „Maritin” lub „Maruscha”, Maria Józefa - „Pepa”, Kunegunda - „Cucu”. Szczególnie blisko był z siostrą Marią Józefą, żoną Delfina Francji. Przez związki małżeńskie rodzeństwa uwikłał się w relacje z większością domów panujących w Europie: cesarstwem, Burbonami we Francji i w Hiszpanii, dlatego rozwój wydarzeń politycznych, nowe małżeństwa czy zgony władców były pieczołowicie odnotowywane przez księcia9

Martange (1722-1806), bliski i serdeczny przyjaciel Ksawerego, jego aide de camp, charakteryzując młodego księcia, zwrócił uwagę, że był to człowiek o dobrym charakterze, sprawiedliwy, trochę nieśmiały w kontaktach z ludźmi, co miało być wynikiem wychowania, jakie otrzymał. Poza tym Wettyn lubił konie oraz psy i chętnie jeździł na polowania ${ }^{10}$. Tak przedstawiony książę wydawał się zupełnie zwykłą osobą, którą wyróżniało jedynie urodzenie. Franciszek Ksawery edukowany był w taki sam sposób, jak całe jego rodzeństwo. Podstawą kształcenia była nauka pisania i czytania, a następnie nauka języków obcych, na czele z językiem francuskim, ale chłopcy ćwiczyli się również w języku polskim. Nie brakowało lekcji gry na instrumentach, śpiewu i wizyt w teatrze ${ }^{11}$. Marszałkiem dworu Franciszka Ksawerego, równocześnie też młodszego brata Karola Krystiana, został Florian Rupert von Wessenberg-Ampinger, który po 1743 r. ustąpił miejsca hrabiemu WackerbarthSalmour. Ten doświadczony człowiek wprowadził chłopców w świat polityki, a formacją wojskową zajął się baron Franciszek J. de Fôrel, komandor Zakonu Kawalerów Maltańskich. Kolejnym wychowawcą (od 1748 r.) został Jan Franciszek Bellegarde, francuski

\footnotetext{
6 Jego pełne imię to François-Xavier- BENNON, Prince de Saxe.

7 J. Staszewski, August III Sas, Wrocław 2010, s. 198.

${ }^{8}$ Listy pochodzą z lat 1750-1790. Arch. Aube, Fonds de Saxe, EE 1486 - EE 1530.

${ }_{9} \mathrm{Z}$ punktu widzenia jego biografii do najważniejszych wydarzeń należała wojna siedmioletnia (1756-1763), sukcesja w Polsce po śmierci Augusta III w 1763 r. oraz administracja Saksonią (1763-1769).

${ }^{10}$ C. Breard, op. cit.

11 J. Staszewski, op. cit., s. 188-190.
} 
oficer na saskiej służbie, który jednak nie potrafił zapanować nad podopiecznymi i po kilku latach zastąpił go szambelan von Kassel. Ksawery miał, podobnie jak jego najstarszy brat, Fryderyk Krystian, polskich paziów ${ }^{12}$. W nauce języka polskiego królewiczowi pomagał ksiądz Antoni Gietulewicz. To polskie otoczenie było wynikiem pobytu rodziny królewskiej w Warszawie w okresie niepokojów wojny siedmioletniej.

Życie Ksawerego diametralnie zmieniło się, gdy rozpoczął służbę wojskową, gdyż właśnie wtedy wkroczył na drogę edukacji, jaką winien był otrzymać każdy młody arystokrata $^{13}$. Kariera w armii nabierała rozpędu. Wiosną 1759 r. Ksawery staną na polu walki pod wodzą marszałka de Broglie, prowadzącego armię francuską. Angażował się również w kolejnych latach wojny siedmioletniej wraz ze swoim bratem Karolem. W 1778 r. został dowódcą dywizji bretońskiej. Same źródła milczą na temat umiejętności militarnych Ksawerego ${ }^{14}$.

Ambitne plany polityczne Franciszka Ksawerego, by objąć tron w Rzeczpospolitej, nie pokrywały się z projektami jego ojca. August III widział koronę polską na głowie swojego najstarszego syna Fryderyka Krystiana. Dla Ksawerego rozpoczął starania o rękę infantki portugalskiej. Polskie plany królewicza wspierane były przez młodszą siostrę Marię Józefę, zabiegającą o poparcie dla brata u swojego teścia, Ludwika XV. Dla księcia, ślub siostry był ważnym wyróżnieniem, gdyż otwierał mu drogę na dwór francuski. Gdy w roku 1759 pojawiała się pogłoska o abdykacji Augusta III z tronu polskiego, Maria Józefa dołożyła wszelkich starań, by to właśnie ulubiony brat stał się kandydatem Ludwika XV, jednakże ten nigdy oficjalnie tego nie uczynił. Bardzo ważnym momentem w karierze Ksawerego była śmierć starszego brata, Fryderyka Krystiana, zaledwie po dwóch miesiącach panowania na saskim tronie (17 grudnia 1763 r.). Franciszek Ksawery objął władzę w imieniu niespełna trzynastoletniego bratanka Fryderyka Augusta III. Zadanie nie było łatwe, gdyż kraj znajdował się w bardzo złym stanie po wojnie siedmioletniej. Ksawery kontynuował wyznaczoną przez zmarłego brata drogę reform. Książę zajął się jeszcze jednym bardzo ważnym zadaniem - edukacją swojego bratanka. Na jego preceptora i guwernera wyznaczył wspomnianego już barona Fôrela. Człowiek ten miał bardzo dobrą opinię, cieszył się szacunkiem, znał biegle język francuski i niemiecki, a co najważniejsze oddał się całkowicie pracy ze swoim podopiecznym ${ }^{15}$. Ksaweremu zależało, by w czasie swojej regencji zbliżyć Saksonię z Francją, jednak ślub Franciszka Augusta III z siostrą elektora bawarskiego w 1769 r. oddalił tę perspektywę, wprowadzając Elektorat w krąg wpływów cesarskich ${ }^{16}$. Równocześnie ogłoszono pełnoletniość młodzieńca i tym samym zakończył się okres regencji księcia.

\footnotetext{
12 Antoniego Miaskowskiego, Stanisława Ankwicza, Felicjana Miraczewskiego, Adama Lubnieckiego, Mateusza Podoskiego i Adama Piotrowicza.

13 C. Terraux, op. cit.

14 Ibidem.

${ }_{15}$ Il conserva à sa nouvelle mission tout ce qui lui restart de force et d'activité. Il se dépensa sans computer, avec un absolu désintéressement, une ténacité invincible et une foi ardente, à computer et à parfaire l'éducation de l'électeur. C. Terraux, op. cit.

${ }^{16}$ Jeszcze za życia Delfiny planowano ślub Fryderka Augusta III z Marią Adelajdą córką Delfina, ale jej śmierć w marcu 1767 r. sprawiła, że projekt nie został sfinalizowany.
} 
Jeszcze w 1769 r. Ksawery wyjechał z Drezna i po krótkim czasie spędzonym w Monachium, udał się w dwuletnią podróż po Włoszech w towarzystwie hrabiny Spinucci. Półwysep Apeniński nie był jednak miejscem, gdzie książę zamierzał osiąść na stałe. Zawsze ciepło przyjmowany we Francji postanowił tam zamieszkać, przyjmując tytuł comte du Lusace, czyli hrabiego Łużyc, nawiązując tym samym do swojego pochodzenia. W roku 1771 kupił pałac i dobra Chaumot, niedaleko Sens. Jednak zbyt duży dystans, jaki dzielił ten majątek od Paryża spowodował, że książę zaczął szukać innej rezydencji. Wybór padł na pałac Pont-sur-Seine, który stał się jego własnością w 1775 r. Środki na utrzymanie zapewniły mu dochody z apanaży w Polsce. Nowy nabytek, choć uważany był za jeden z piękniejszych we Francji, zdaniem nowego właściciela należało jeszcze dodatkowo upiększyć, co pochłonęło niemałe środki. Zamek stał się luksusową rezydencją. Ksawery musiał zacząć rozsądniej dysponować pieniędzmi. Osiedlenie się z całą rodziną w Pont-sur-Seine sprawiło, że mógł on spędzać z nią znacznie więcej czasu. $\mathrm{Z}$ dużo większym zaangażowaniem zajmował się sprawami związanymi z dziećmi, a zwłaszcza ich edukacją. Pozostawały one pod opieką matki i zaufanych nauczycieli oraz guwernantek.

Równolegle do rozwijającej się kariery wojskowej, książę ustabilizował swoje życie osobiste. W 1765 r. zawarł ślub morganatyczny z hrabiną Klarą-Marią Spinucci. Małżeństwo wywołało skandal na dworze drezdeńskim - powątpiewano w błękitną krew wybranki, podkreślając jednak jej wielką urodę ${ }^{17}$. Przypieczętowaniem dobrej passy w życiu rodzinnym było zakończenie długich negocjacji w Rzymie w celu uznania tego małżeństwa, o czym skwapliwie powiadomił swoją siostrę Kunegundę: Je ne veux pas vous laisser ignorer qu'avançant chaque jour en âge, je viens de déclarer mon mariage avec la cara Chiaretta et d'assurer par là son état et celui de nos enfants ${ }^{18}$.

Ze związku z hrabiną Spinucci Kswery miał dziewięcioro dzieci. Elżbieta-UrszulaAnna-Cordule-Ksawera urodziła się w roku 1768 w Dreźnie. Jej młodsza siostra MariaAnna-Violante-Katarzyna-Marta-Ksawera przyszła na świat w roku $1770 \mathrm{w}$ czasie podróży po Półwyspie Apenińskim w Sienie. Pierwsze lata życia upłynęły dwóm córkom w Chaumot lub w Pont-sur-Seine. Następnie zostały posłane w roku 1778 do sióstr wizytek w Paryżu (couvent de la Visitation de Sainte Marie), gdzie spędziły cztery lata, by zostać przeniesione do opactwa Panthémont. Elżbieta, jako siostra cioteczna króla, stanowiła bardzo dobrą partię, dlatego trudno było znaleźć dla niej odpowiedniego kandydata na męża, który uzyskałby akceptację Wersalu. Ostatecznie w roku 1787 wyszła za mąż za księcia d'Esclignac. Maria Anna, podobnie jak starsza siostra, czekała na odpowiedniego kandydata do swojej ręki. Wybór padł na neapolitańskiego księcia di Sanseverino. $\mathrm{O}$ trzech kolejnych córkach nie wiemy zbyt wiele: Beatrycze-Maria-Franciszka-Brygida ur. $1772^{19}$, Kunegunda-Anna-Helena-Maria-Józefa ur. 1774 w Chaumot, Krystyna-Sabina

\footnotetext{
${ }^{17}$ Cyt. za J.-J. Vernier, Inventaire..., s. XXXIX.

18 A.Thévenot, op. cit., s. 26.

19 Przechowywana w Archiwum departamentalnym Aube korespondencja wskazuje, że Beatrycze przebywała ze starszymi siostrami w Pont.
} 
ur. 1775 w Pont-sur-Seine ${ }^{20}$. Dwoje dzieci zmarło w wieku dziecięcym: Klara, krótko po narodzinach, a Cecylia mając osiemnaście miesięcy (ur. 17.12.1779 - zm. 1781). Zgon drugiej córki znalazł odbicie w zachowanej korespondencji księcia z żoną Klarą, z której wynika, że był to dla niego duży $\operatorname{cios}^{21}$.

Najstarszy syn, Ludwik-Rupert-Józef-Ksawery, urodził się w roku 1766 w Dreźnie (jego siostra bliźniaczka zmarła) i został przeznaczony do stanu duchownego. Jego młodszy brat Józef-Ksawery-Karol-Rafael-Filip-Bénit Chevalier de Saxe przyszedł na świat rok później, także w Dreźnie ${ }^{22}$. Na guwernera chłopców został wyznaczony duchowny Barruel i zajmował się nimi do 1778 r., gdyż wtedy chłopcy zostali umieszczeni w Collège de Navarre w Paryżu. Po zakończeniu nauki, w 1780 r. Ludwik otrzymał święcenia. Zmarł w czasie pobytu w seminarium oriatoriańskim świętego Magloire w Paryżu, mając zaledwie 17 lat. Młodszy brat Ludwika, Józef, wybrał zupełnie inną drogę - karierę wojskową. Naukę w tym kierunku podjął w École Militaire w Paryżu, a w wieku 15 lat otrzymał tytuł Kawalera Zakonu Maltańskiego. Jednak nauka w szkole nie interesowała go zbytnio, wolał oddawać się ćwiczeniom fizycznym i paradom wojskowym. W $1788 \mathrm{r}$. został oficerem w regimencie hrabiego Prowansji z tytułem aide de campe marszałka Broglie. Są to ostatnie informacje, jakie posiadamy o księciu Józefie przed jego śmiercią w 1802 r. w Niemczech ${ }^{23}$.

Przeprowadzka do Pont-sur-Seine nie oznaczała końca podróży Ksawerego. W 1776 r. wyruszył do Szwajcarii, a następnie odwiedził dolinę Renu i Pireneje. W końcu 1790 r. książę zdawał sobie sprawę, że niepokoje we Francji zagrażają jego życiu, a status arystokraty zagranicznego nie gwarantuje nietykalności. Zmuszony do opuszczenia Pontsur-Seine udał się do Saksonii. Tym samym archiwalia z okresu 1791-1806 znajdują się zapewne w archiwach niemieckich. Franciszek Ksawery zmarł 21 czerwca 1806 r. w swoim majątku Zabeltitz, koło Drezna. Zamek Pont-sur-Seine, gdzie zgromadzono imponujące archiwum rodzinne, zniknął wraz z kresem Cesarstwa. W 1791 r., wraz z wyjazdem właściciela, domena została przejęta przez ówczesne władze rewolucyjne. Splądrowały one wnętrze z wszelkich luksusowych przedmiotów. Ostateczny cios zadany został zamkowi w czasie I wojny światowej - ograbiono go, spalono i w końcu całkowicie zniszczono.

Wśród zachowanych materiałów osobistych księcia Franciszka Ksawerego uwagę zwracają papiery dotyczące wychowania i kształcenia dzieci. Poświadczone są zabiegi edukacyjne zarówno wokół synów, jak i córek. Są to listy od potomstwa, ich wychowawców i guwernerów, dokumenty ze szkół, do których chodziły. Korespondencja związana z dziećmi, ich wychowaniem i życiem obejmuje w zespole Fonds de Saxe sygnatury EE

\footnotetext{
${ }^{20}$ Zachowały się jej listy do ojca z 1778 r., które zapewne pisał ktoś inny w jej imieniu, gdyż dziewczynka miała wtedy 3 lata. Arch. Aube, Fonds de Saxe, 1477/3.

${ }^{21}$ Listy Klary de Spinucci do Ksawerego de Saxe z 1781 roku. Arch. Aube, Fonds de Saxe, EE 1544/C, k. 1086-1097.

${ }^{22}$ Dzieci zostały naturalizowane w $1781 \mathrm{r}$.

23 J.-J. Vernier, Inventaire sommaire des Archives Départementales de l'Aube, Serie E* (Fonds de Saxe), t. I, Troyes 1903, s. XV.
} 

dotyczą córek ${ }^{24}$.

Więcej uwagi poświęcimy archiwaliom dotyczącym panienek saskich, gdyż rzucają one światło na relacje ojca z córkami oraz ich edukację. Przykładem mogą być listy Elżbiety do Ksawerego. Zachowało się kilkadziesiąt listów Elżbiety de Saxe do ojca z lat 1776-1790. Najstarszy z nich napisała, gdy miała 8 lat. Zapewne nie była to pierwsza wprawka epistolarna, gdyż styl wskazuje, że nie raz ćwiczyła już pióro w standardowych formułkach, zapewniających ojca o swoim uczuciu i oddaniu. Dorosła już córka pisała o wszystkim, dostarczając informacji o każdym szczególe swojego życia: radościach z zabaw karnawałowych, spotkaniach towarzyskich, podróżach, uczuciu do męża, mamkach dla pojawiającego się potomstwa. Dzieliła się swoimi emocjami, troskami związanymi z następującymi po sobie ciążami, tęsknotą za rodziną, a zwłaszcza za ukochanym papa. Wskazówki od ojca, choć spisywane na odległość, zawsze były dla oddanej córki cenne ${ }^{25}$.

Korespondencja młodszych córek, Marii Anny, Beatrycze Marii oraz Krystyny Sabiny to jedynie kilka sztuk z lat 1777-1778 i brakuje w nich informacji dotyczących życia codziennego. Wszystkie dziewczęta stworzyły czterowierszowe, rymowane wierszyki i starannie wykaligrafowały ${ }^{26}$.

Informacji o wychowaniu i nauce mesdemoiselles de Saxe dostarczają trzy typy źródeł: korespondencja, instrukcje dotyczące wychowania i kształcenia oraz pozostałe dokumenty związane z okresem ich panieństwa, takie jak chociażby Permission du Roi autorisant les princesses Elisabeth et Marie-Anne à solliciter une dispense de Rome pour obtenir des pensions sur des bénéfices ecclésiastiques ${ }^{27}$.

Droga, jaką wybrał Franciszek Ksawery w edukacji córek, wydaje się charakterystyczna dla dziewcząt z rodów książęcych. Demoiselles de Saxe musiały uczyć się języków obcych: francuskiego, niemieckiego i włoskiego. Szczegółów dotyczących metod, jakie stosowano w czasie lekcji językowych, dostarcza opis sporządzony przez Szymona Schamberga, nauczyciela języka niemieckiego, zatytułowany Le meilleur et la méthode la plus aisée pour entretenir les Demoiselles de Saxe dans les langues... Tekst ten powstał w kwietniu 1781 r. w Paryżu. Zachował się jednak kontrakt już z maja 1778 r., w którym zapisano, że panienki mają mieć lekcje 3 razy w tygodniu. Schamberg uczył w tym okresie także synów Ksawerego oraz, jeżeli pozostałe obowiązki pozwalały, dawał także dziewczętom lekcje języka włoskiego. W Le meilleur et la méthode... w pięciu punktach relacjonuje, jak należy postępować, aby nauka była jak najskuteczniejsza.

\footnotetext{
${ }^{24}$ Materiały związane z synami i ich guwernerami to sygn. EE 1459-1460, 1462-1473, 1661, 1773-1788.

${ }^{25}$ Listy Elżbiety do księcia Ksawerego de Saxe z lat 1776-1790. Arch. Aube, Fonds de Saxe, EE 1474.

26 Jako przykład można zacytować utwór kilkuletniej Marii Anny:

Si de parler, j'avois le don,

Du aujourd'hui je serois bien aise

De dire du papa à mon aise

Je vous aime comme le bonbon.

Wiersz Marii Anny de Saxe do ojca. Arch. Aube, Fonds de Saxe, EE 1477.

27 Permission du Roi autorisant les princesses Elisabeth et Marie-Anne à solliciter une dispense de Rome pour obtenir des pensions sur des bénéfices ecclésiastiques z 30 kwietnia 1786 roku. Arch. Aube, EE 1478/3.
} 
Przede wszystkim nakazywał dyktanda, samodzielną pracę ze słownikiem, ćwiczenia w pisaniu, wymowie. Zalecał naukę na pamięć i regularne powtarzanie. W drugim punkcie zwrócił uwagę, że nauka języków obcych, poprzez dobór tekstów i słownictwa, może edukować również w tematach konwersacji, moralności, historii i epistolografii. Podkreślił, że nie chodzi tu o sztywną znajomość gramatyki, za którą nie idzie rzeczywista umiejętność, która fait un langage de perroquet dont elles ne coprennent rien et n'a nulle utilité2 ${ }^{28}$. Schamberg podał też przykłady możliwe do wykorzystania w czasie doskonalenia poszczególnych umiejętności. Kolejne punkty to zalecenia dotyczące demoiselles. Rzucają one cień nie tylko na umiejętności córek, ale także na ich charaktery. Elżbieta miała problemy z wymową (zbyt miękką) oraz czytaniem (tym razem były kłopoty z dykcją). Była jednak uczennicą, która podporządkowywała się nauczycielowi, choć czasem zbyt powolna, potrzebowała dodatkowej motywacji. Maria Anna ma, zdaniem nauczyciela, wrodzone zdolności i zadziwiającą łatwość w nauce języków obcych, ale wszystko zależy od jej humorów i chwilami od bardzo żywego temperamentu. W swej instrukcji Schamberg zwracił jednak uwagę, że konieczne jest uwzględnienie tak różnych charakterów i dostosowanie do nich metod wychowawczo-edukacyjnych. Kolejne karty ukazały nam i inne cechy charakteru uczennic, które wymagają korekty. Główną wadą Elżbiety miało być lenistwo, które wypływało z jej humorów i przesadnej delikatności, a jej zrywy do pracy nie trwają zbyt długo. Jednak dorastająca panienka zdawała sobie sprawę z tych słabości. Maria Anna była za to bardzo uczuciowa, co można było wykorzystać przy motywacji do nauki. Jeszcze trochę dziecinna (od swojej starszej siostry była młodsza o dwa lata) miała opinię lekkoducha, która lubiła narzucać swoją wolę rówieśnikom. Jej skłonność do zabawy sprawiła, że w oczach wychowawcy potrzebowała reguł, które wytyczyłyby jej porządek. Łatwość z jaką przychodziła jej nauka, działała na nią demotywująco, przez co nie wykorzystywała swoich możliwości ${ }^{29}$.

Jak już zostało wspomniane Elżbieta i Maria Anna zostały wysłane do szkoły przy klasztorze Sióstr Wizytek w Paryżu, gdzie uczyły się i mieszkały przez trzy lata. Jak zwraca uwagę francuska badaczka Dominique Godineau nauczanie nie było priorytetem dla tego zgromadzenia, w odróżnieniu od urszulanek i sióstr Zgromadzenia Notre-Da$\mathrm{me}^{30}$. Wszystkie wspomniane zakony przyjmowały na pensję dziewczęta $\mathrm{z}$ rodzin szlacheckich i bogatej burżuazji. W naturalny sposób część z panienek pozostawała za murami klasztornymi na zawsze. Inne dziewczęta, zwłaszcza w drugiej połowie XVIII stulecia, opuszczały go, by wziąć ślub i wkroczyć w życie towarzyskie elit ${ }^{31}$. Plan dnia w takiej szkole wyznaczał rytm praktyk religijnych: pobudka między godziną 4 a 7 rano, modlitwy, msza święta, śniadanie, zajęcia lekcyjne, modlitwy, obiad, któremu towarzyszyła lektura pism pobożnych, przerwa, zajęcia lekcyjne, nieszpory, podwieczorek, katechizm, modlitwy, kolacja i lektura pobożna, odpoczynek, spowiedź, modlitwy. Na spo-

\footnotetext{
${ }^{28}$ Czyni z języka perukę, z którego nic nie rozumieja, i do niczego nie jest potrzebny. Ibidem, k. 24-25.

${ }^{29}$ Ibidem, k. 21.

30 D. Godineau, Les femmes dans la Socie française $16^{e}-18^{e}$ siècle, Paris 2003, s. 129.

$31 \mathrm{Na}$ edukację na wysokim poziomie, która przygotowywała właśnie do życia światowego, była założona w 1686 r. szkoła Saint-Cyr pani de Maintenon.
} 
czynek udawano się między godziną 20 a 21. Przy tak rozplanowanym dniu na naukę poświęcano ok. 5-6 godzin. Na ową edukację składały się trzy elementy: religia z niewielkimi naleciałościami etyki, podstawy czytania, pisania i liczenia oraz szycia $i$ haftowania $^{32}$. Dla panienek z dobrze sytuowanych domów, które miały zostać wydane za mąż po wyjściu ze szkoły klasztornej, istniała możliwość opłacenia lekcji z dodatkowymi nauczycielami rysunku, muzyki, śpiewu, tańca. Prowadzący szkołę zastrzegali sobie, co znajduje się w opłacie rocznej, a co należy dodatkowo opłacić. Franciszek Ksawery musiał, dla uzupełnienia podstawowej edukacji, dopłacić jeszcze lekcje z nauczycielem muzyki oraz gry na klawesynie, rysunku ${ }^{33}$, geografii i historii. Nauczyciela języków obcych należało znaleźć we własnym zakresie ${ }^{34}$.

Umowa przyjęcia córek Franciszka Ksawerego precyzowała nie tylko sprawy odbywania lekcji, a właściwie przede wszystkim kwestie związane z warunkami życia oraz wyposażeniem panienek. Po uporządkowaniu w grupy poszczególnych przedmiotów (meble, naczynia kuchenne, bielizna, ubrania) zaznaczono wyraźnie, co musi zostać dostarczone przez księcia, a co zapewnia klasztor. Ten prosty sposób, praktykowany powszechnie, pozwalał na uniknięcie niepotrzebnego zamieszania w chwili przybycia do szkoły i równocześnie gwarantował, że panienki będą w swoim wyglądzie i uposażeniu względnie podobne. Szkoła sformułowała w swojej umowie liczne zastrzeżenia, podkreślając wyraźnie, za jakie usługi zorganizowane przez placówkę należy dopłacić (np. dentysta). Zaznaczono także, co rodzina winna zorganizować we własnym zakresie (m.in. lekarstwa). Lista potrzebnej bielizny osobistej i pościelowej oraz ubrań była długa. Zakupy częściowo poczyniono u kupca Herarda. Tak przygotowane panienki mogły rozpocząć kształcenie w szkole przyklasztornej.

Kolejnych informacji o sposobie edukacji córek Franciszka Ksawerego dostarczają teksty znajdujące sie na kartach 1-5 poszytu EE 1478/2 z zespołu Fond de Saxe. Szczególnie interesujące jest zestawienie obowiązków, jakie miały wypełniać osoby zajmujące się dziewczętami, a autorami tych wytycznych była para książęca, zatytułowane L'intention de Mgr et Madame la comtesse de Lusace concernant l'éducation de mesdemoiselles de Saxe est ce qui suit dans les articles énoncés ci-dessous. Tekst ten pochodzi z 1778 lub 1779 r. ${ }^{35}$ Uporządkowana w 16 punktach instrukcja precyzowała przebieg dnia, relacje pomiędzy panienkami a ich guwernantką Madame de Milchéon, wyznaczała liczbę służby oraz zakres jej działań. Osoba spisująca wolę rodziców wyraźnie podkreśliła ich osobiste zaangażowanie w układanie planu dnia i obowiązków. Pani de Milchéon zobowiązana została do bardzo dokładnego relacjonowania wszystkich wydarzeń. Taki nadzór wydawał się konieczny z perspektywy Ksawerego i jego małżonki, w związku z ich częstymi nieobecnościami. Stała kontrola rysowała się wręcz jako niezbędna, zwłaszcza jeśli weźmiemy pod uwagę przywołane wcześniej spostrzeżenia Schamberga o krnąbrno-

\footnotetext{
${ }^{32}$ Histoire des femmes en Occident, t. 3, $\mathrm{XVI}^{\mathrm{e}}-\mathrm{XVIII}{ }^{\mathrm{e}}$ siècle, red. Natalie Zemon Davis i Arlette Farge, Paris 2002, s. 160.

33 Słowo rysunek zostało przekreślone. Memoire de ce qu'il faut pour les Delles Pensionaires en entrant... Arch.Aube, Fonds de Saxe, k. 6.

${ }^{34}$ Ibidem.

35 Arch. Aube, Fonds de Saxe, EE 1478/2, k. 3-5.
} 
ści, lenistwie i żywym temperamencie dziewcząt. Powszechnie wiadomo było, że książę chciał być dokładnie i regularnie informowany o wszystkim, co dzieje się w jego zamku i dobrach. Pouczał swojego zarządcę pana Herbillona: Je crois vous savoir deja dit avant mon depart de me faire regulierementvotre raport chaque semaine de tout ce qui se passe a Pont, et de ce qui concerne les departements dont vous êtes charge actuellement ${ }^{36}$. Jak już wspomnieliśmy dyspozycje powstały około 1778 r., a więc w czasie, gdy książę wypełniał swoje obowiązki w armii. Rodzice oczekiwali, że opiekunka nie będzie odstępować panienek i kontrolować każdą ich rozmowę. Z pewnością musiała mieć posłuch i szacunek u dziewcząt. Te miały zwracać się do niej bonne amie, co miało w konsekwencji, choć pozornie, ocieplić sztywne relacje ${ }^{37}$. Bo z pewnością nie łatwo było o serdeczne kontakty z osobą, która według zaleceń rodziców miała nie odstępować dziewcząt ani w trakcie posiłków, ani w czasie wolnym od nauki, towarzyszyć w spotkaniach z księciem i jego żoną. W chwili gdy Mme de Milchéon nie przebywała z panienkami, towarzyszyły im dwie służące, które wszystko musiały zgłaszać guwernantce. Matka pozostawiła sobie pieczę nad ubraniami ${ }^{38}$. Bardzo istotnym wskazaniem od pary książęcej było nakazanie, by córki obowiązywały te same godziny lekcji, jak braci. Podkreślono, że zajęcia z pisania i czytania, prowadzone przez duchownego, prowadzone będą po modlitwach i śniadaniu, zawsze w towarzystwie Pani de Milchéon. Istotnym zastrzeżeniem był fakt, że nauczyciel miał tylko i wyłącznie prowadzić lekcje, a nie zajmować się wychowaniem. W jego zakres nie wchodziło nagradzanie i karanie ${ }^{39}$.

Treści merytorycznych i listy lektur, jakie były oczekiwane przez rodziców i w jakim stopniu zostały realizowane w czasie zajęć z duchownym, nie znamy. Zachował się jednak spis książek Elżbiety i Marii Anny, jakie zabrały ze sobą do szkoły sióstr wizytek ${ }^{40}$. Jest to lista 19 pozycji, w języku francuskim i włoskim (w tym 8 wraz z dubletami, 2 wydawnictwa dwutomowe oraz 8 pojedynczych, jeden wpis jest nieczytelny). Wśród nich znajdują się przede wszystkim książki pobożne (11 tytułów). Mniejszą grupę stanowią podręczniki do nauki języków obcych oraz słowniki (5 tytułów) ${ }^{41}$. Dwie pozycje pozostają poza tymi grupami: Voyage de Sophie oraz Histoire edifiante, jednak obie o charakterze moralizującym. Dodatkowe tytuły przynosi drugi spis, już znacznie krótszy, bo liczący trzy pozycje (dwie w języku francuskim, jedna w języku niemieckim). Wśród nich znana w wieku XVIII książka do gramatyki niemieckiej Johanna Ch. Gottscheda oraz kazania w czterech tomach ojca Harnischa.

\footnotetext{
${ }^{36}$ List od księcia Ksawerego de Saxe do Herbillon, archiwisty i zarządcy w zamku Pont-sur-Seine z 19 maja 1778 roku. Arch. Aube, Fonds de Saxe, EE 1458/1, k. 24.

${ }^{37}$ Ibidem.

${ }^{38}$ Au sujet des habits, garde-robe etc, ce sera Madame la comtesse de Lusace qui en ordonnera. Ibidem.

${ }^{39}$ L'aumonier n'aura nulle autorité concernant les récompenses et punitions, sa mission n'étant que les leçons et non l'éducation. Ibidem.

${ }^{40}$ Etat des livres des Mesdemoiselles de Saxe au covent de la Visitation Sainte-Marie. Ibidem, k. 17.

${ }^{41} \mathrm{~W}$ tym Grammaire allemande zapewne Johanna Ch. Gottscheda oraz Le Maitre Italien, być może chodzi o Le Maitre Italien par le Sieur Veneroni, revu, corr. et augm. d'un Maître François... par Louis de L'Epine. La Grammaire allemande de M. Gottsched... mise en françois par M. G. Quand, Paris 1754; Le Maitre Italien par le Sieur Veneroni, revu, corr., et augm. d'un Maître François... par Louis de L'Epine, Paris 1735 .
} 
$\mathrm{Z}$ anonimowej relacji, być może guwernantki, wynika, że panny saskie spędzały ok. 6-7 godzin dziennie na nauce ${ }^{42}$. Codziennie, przez godzinę, doskonaliły umiejętność gry na klawesynie. Lekcje same muzyki były trzy razy na tydzień, z obowiązkiem samodzielnych codziennych ćwiczeń. Również trzykrotnie w tygodniu przez trzy kwadranse uczyły się geografii. Równie często prowadzone były lekcje języków obcych, lecz w dni, w które nie przychodził nauczyciel, dziewczęta musiały ćwiczyć same, w swoim pokoju. Nauka religii trwała 45 minut, które pozwalały na powtórzenie nauczycielce zadanej lekcji. Elżbieta uczyła się dodatkowo każdego dnia historii starożytnej oraz ćwiczyła pod okiem nauczyciela sztuki rysunku, gdyż ta druga umiejętność była na tyle słabo rozwinięta, że wymagała jeszcze dalszego instruktażu. Całość uzupełniała półgodzinna lektura tekstów pobożnych oraz śpiewanie modlitw, uczestnictwo w dodatkowych modlitwach porannych i wieczornych oraz mszy św. W ciągu tak wypełnionego dnia pozostawało niewiele wolnego czasu, który i tak był zagospodarowywany przez kobiece prace ręczne (przędzenie), gdyż panienka nie powinna była nigdy siedzieć bezczynnie. Sądzono przecież, że z braku zajęć mogłyby do głowy młodej dziewczyny przyjść jakieś grzeszne myślitis.

Jak pobyt w domu pod opieką matki, z dyspozycjami pozostawionymi przez ojca, postrzegały dziewczęta, dowiadujemy się z listu Elżbiety (podpisywała się Lise) do Madame de Chery, którą nazywa ma chere petite mere oraz ma chere petite amie ${ }^{44}$. W tajemnicy przed matką, dziewczyna postanowiła wyżalić się, po powrocie z Panthémont do Pont. Jedyną jej towarzyszką była Teresa, zapewne panna do towarzystwa, która mogła przebywać z nią w pokoju. Elżbieta po prostu nudziła się z powodu braku atrakcji i towarzystwa, choć były tam jej matka oraz siostry Maria Anna i Beatrycze ${ }^{45}$. Powoli upływający czas miały ożywić liczne spacery i jazda konna, a także zarządzone przez rodziców lekcje w domu, potem w szkole klasztornej. Czujna kontrola każdego kroku, z perspektywy rodziców, miała przynieść owoce, gdy dziewczęta będą już dorosłe.

W świetle korespondencji dziewczęta miały w czasie pobytów w Pont lub Chaumont kilka guwernantek. Pierwszą znaną była pani Favier. Jej listy pochodzą z lat 1774-1778 i wysłane zostały zarówno z Pont-sur-Seine, jak i Chaumont ${ }^{46}$. Były spisywane regularnie, co 4-5 dni. Gdy guwernantka rozpoczęła opiekę nad dziewczynkami, najstarsza z nich - Elżbieta miała 6 lat. Ojciec mógł czytać nie tylko o postępach w nauce, ale również o formacji moralnej. Pani Favier czujnie obserwowała swoje podopieczne, skrzętnie przekazując, jak zachowywały się nie tylko w czasie wolnym. Odnotowała epizod, jaki miał miejsce wiosną 1775 r. - dziewczynki, Elżbieta i Beatrycze, zbierały po kryjomu okruszki, starannie chowając je do kieszeni. Gdy zostało to odkryte wyjaśniły, że to dla biednych, których widziały wcześniej. Oczywiście pani de Favier zezwoliła na

\footnotetext{
${ }^{42}$ Tekst nie posiada żadnego tytułu czy nagłówku. Arch. Aube, EE1478/2,k. 20.

43 D. Żołądź-Strzelczyk, Dziecko w dawnej Polsce, Poznań 2006, s. 216.

${ }^{44}$ List Elżbiety de Saxe do Madame du Chery z 2 maja 1785 roku z Pont (kopia). Arch. Aube, Fonds de Saxe, EE1477, k. 19-20.

${ }^{45}$ Mon Dieu que je m'ennuie ici, ecrivez moi je vous en pris, ma chère, bientôt. Ibidem, k. 20.

${ }^{46}$ Listy pani de Favier do księcia Ksawerego de Saxe z Pont-sur Seine z lat 1774-1778. Arch. Aube, Fonds de Saxe, EE 1482.
} 
zaniesienie drobinek chleba, widząc w tym wspaniałą, bo praktyczną, lekcję miłosierdzia i dobroczynności ${ }^{47}$.

W okresie od stycznia do marca 1778 r. była to panna Vanesbeck, pod której skrzydłami były Elżbieta, Maria Anna, Kunegunda, Beatrycze i Krystyna. Opiekunkę najbardziej cieszyły postępy panienek w poznawaniu religii, doskonaleniu znajomości modlitw oraz skupieniu na mszach, o czym skwapliwie donosiła ich ojcu, który niczego nie bagatelizowa ${ }^{48}$.

Zakonnica Mme de Nollet opiekowała się dziewczętami w klasztorze Sióstr Wizytek w Paryżu. W maju 1778 r. pisała do hrabiny Spinucci o postępach w nauce dziewcząt, a cztery lata później dokładnie relacjonowała przygotowania do ważnego wydarzenia pierwszej Komunii córki ${ }^{49}$.

W okresie 1780-1788 guwernantką była pani Bardon de Bellegarde, pierwotnie dama do towarzystwa księżnej de Lusace, matki dziewcząt. Należy podkreślić, że dziewczęta w ciągu tych ośmiu lat przebywały jeszcze przez dwa lata w szkole klasztornej. Oczywiście książę Ksawery mógł liczyć na solidne relacje z postępów w nauce i zachowaniu. W liście z 14 grudnia 1785 r. pani de Bellegarde skupiła się na Marii Anny, która nieustannie wymagała motywacji, aby jej rozwój postępował w zadowalającym tempie ${ }^{50}$. Panna Eglé de Bellegarde, córka madame Bardon de Bellegarde, zajmowała się właśnie w tym okresie (w 1786 r.) Beatrycze. Ale nie tylko. Jeździła konno z Elżbietą, przygotowywała atrakcje z okazji urodzin hrabiny, w tym przedstawienie, którego autorką była Kunegunda. Zawsze jednak odwoływała się do opinii ojca: J'espère que Votre Altesse trouvera bon que Mesdames de Saxe s'occupent d'un petit amusement qui plaise à la Princesse leur mère ${ }^{51}$.

W szkole klasztornej dziewczęta znalazły się oficjalnie pod opieką ksieni Marii Katarzyny de Béthisy de Mézières $^{52}$, gdzie wysłane zostały jesienią 1782 r. Placówka przy Abbaye Royale de Panthemont była znana nie tylko w Europie, ale i w Ameryce. To właśnie do niej, w roku 1787 wysłał swoją córkę Martę Tomasz Jefferson, która dołączyła tam do starszej siostry Marii i spędziła pięć lat. Opactwo przyjmowało zarówno dziewczęta wywodzące się z elit, które chciały przyjąć habit, jak i te, które miały jedynie zdobyć wykształcenie. Równocześnie wydzielono pomieszczania, w których zamieszkać mogły zamożne, starsze damy. Właśnie tę szkołę utrwalił na kartach markiz de Sade: Styszeliście o tym sławnym opactwie $i$ wiecie, że od dawna stamtąd właśnie wychodza

47 List pani de Favier de księcia Ksawerego de Saxe z 29 marca 1775 roku. Atch. Aube, Fonds de Saxe, EE 1482, k. 32-33.

${ }^{48}$ Listy panny Vansbeck do księcia Ksawerego de Saxe (styczeń-marzec 1778 roku). Arch. Aube, Fonds de Saxe, EE 1485, k. 1-17.

49 Arch. Aube, Fonds de Saxe, EE 1484, k. 8-9.

${ }^{50}$ List pani de Bellegarde do księcia Ksawerego de Saxe z 14 grudnia 1785 roku z Pont. Arch. Aube, Fonds de Saxe, EE 1479 k. 50-51.

${ }^{51}$ List panny de Bellegarde do księcia Ksawerego de Saxe z 2 sieprnia 1786 roku; zob. także list tej do tegoż z 15 sierpnia 1786 roku. Arch. Aube, Fonds de Saxe, EE 1480.

52 Ksienia była bardzo dynamicznym zarządcą opactwa Panthemont (Pentemont) i powierzyła jego przebudowę architektowi królewskiemu d'Ivry. Prace budowlane zakończone zostały w 1783 r., ale w związku z brakiem pieniędzy nie wykończono dekoracji. 
w świat najpiękniejsze i najbardziej wyuzdane kobiety Paryża. Trudno powiedzieć, czy właśnie przez ten pryzmat panny saskie postrzegały swoją szkołę, ale z pewnością dobrze się tam czuły i nie nudziły się ${ }^{53}$. Ksienia była zadowolona z zachowania i postępów dziewcząt, o czym na bieżąco informowała księcia Ksawerego ${ }^{54}$. W okresie gdy panny Elżbieta, Maria Anna i Beatrycze przebywały w Panthémont o postępach w nauce i zachowaniu do księcia pisała również Mme de Fay, przełożona opactwa. Przyjęła ona strategię konsultowania każdej decyzji związanej z córkami Ksawerego. Uznała stanowczo: Je me suis fait une loi de ne rien faire pour mes dames de Saxe sans le communiquer à son altesse ${ }^{55}$. Zdanie ojca było decydujące, zwłaszcza że Mme de Fay chciała, aby dziewczęta grały w sztuce teatralnej pani de Genlis, osoby bardzo znanej wówczas w Europie. Zakonnice czuły się związane z dziewczętami, swoimi pupilles i bardzo żałowały, że demoiselles odchodzą wraz z końcem lata 1784 r. Ksienia znała panią de Bellegarde, pod skrzydła której miały wrócić dziewczęta. Miała o niej dobre zdanie, co podkreśliła W swoim liście ${ }^{56}$. Wydaje się, że para książęca nie mogła narzekać na brak chętnych do objęcia posady guwernantki dla córek, gdyż starała się o nią co najmniej jeszcze jedna dama, Mme Garault de Merville ${ }^{57}$.

Ksawery interesował się także wnukami. Z listów Elżbiety do ojca wynika, że ciąże były dla niej czasem wyjątkowym, pełnym wyczekiwania i tymi chwilami dzieliła się z ojcem: [...] car il me tarde fort d'être débarassée de mon petit paquet non qu'il m'incommode beaucoup; mais j'ai un grand désir de faire connaissance avec cet illustre personnage ${ }^{58}$. Córka przekazywała ojcu nie tylko swoje przeżycia, ale prosiła go o wsparcie: je compte beaucoup sur votre bonté de me donner des soins dans ce moment ${ }^{59}$. Druga ciąża, w 1790 r., zapewne również ucieszyła księcia Ksawerego, którego Elżbieta tym razem poprosiła o przywiezienie z Italii pain au chocolat $!^{60}$. Listownie nadchodziły do niego wieści o kolejnych narodzinach. Henryk d'Esclignac, mąż Elżbiety, szczęśliwy ojciec z dumą pisał, że żona powiła un gros garçon o imieniu Ksawery ${ }^{61}$. Te same wydarzenia opisała w liście do księcia madame Legardouch, teściowa Elżbiety. Przekazała informacje, zapewne te, które najbardziej interesują zatroskanego ojca młodej mamy, że córka czuje się dobrze, a niedługi poród przebiegł pomyślnie i bez większych cierpień.

\footnotetext{
${ }^{53}$ List Elżbiety de Saxe do Madame du Chery z 2 maja 1785 roku, op. cit.

${ }^{54}$ List Mme de Béthisy do księcia Ksawerego z 19 sierpnia 1783 roku z Panthemont. Arch. Aube, Fonds de Saxe, EE 1481.

${ }_{55}$ List Mme de Fay do Ksawerego de Saxe z 2 listopada 1783 roku z Panthemont. Arch. Aube, Fonds de Saxe, EE 1483/1.

${ }^{56}$ List Mme de Fay do Ksawerego de Saxe z 22 sierpnia 1784 roku z Panthemont. Arch. Aube, Fonds de Saxe, EE1483/1.

${ }^{57}$ List Mme la comtesse Garault de Merville do księżnej de Spinucci z 16 sierpnia 1784 roku, Arch. Aube, Fonds de Saxe, EE1483/2.

${ }^{58}$ List Elżbiety de Saxe do Ksawerego de Saxe z 9 października 1788 roku. Arch. Aube, Fonds de Saxe, EE 1474, k. 50.

59 List Elżbiety de Saxe do Ksawerego de Saxe z 6 września 1788 roku. Ibidem, k. 44.

${ }^{60}$ Elżbieta do Ksawerego de Saxe z 27 kiwetnia 1790 roku z Castillon. Arch. Aube k. 72.

${ }^{61}$ Elżbieta urodziła syna 18 października o godz. 18.30. List Henryka d'Esclignac do Ksawerego de Saxe z 21 października 1790 roku. Arch. Aube, Fonds de Saxe, EE 1475, k. 56-57.
} 
Zapewniła, że Elżbieta była i jest otoczona dobrą opieką przez akuszerkę o wysokich kwalifikacjach. Wnuk, choć może nie tak duży jak starsza siostra, był obdarzony bardzo silnym głosem i imponującymi włosami, jak u Adonisa ${ }^{62}$.

Już tak krótka prezentacja zawartości zespołu Fonds de Saxe w Archiwach departamentalnych Aube, skupiając się jedynie na córkach, pokazuje, że materiał ten ma duży potencjał do wykorzystania w badaniach życia rodzinnego i edukacji w drugiej połowie XVIII w.

Franciszek Ksawery de Saxe starał się być aktywnym uczestnikiem życia rodzinnego. Utrzymywał stały kontakt z córkami, także gdy były dorosłe. Równocześnie przez cały okres panieństwa kontrolował ich życie, aby ich formacja intelektualna i duchowa utrzymana została na jak najwyższym poziomie, godnym córek księcia.

${ }^{62}$ List Mme Legardouch do Ksawerego de Saxe z 21 października 1790 roku. Atch. Aube, Fonds de Saxe, EE 1476, k. 30-31. 